WORKING PAPER NO. 19

Nov 1997

\title{
What Futures for the People of the Tropical Forests?
}

Neil Byron and Michael Arnold

\begin{abstract}
Summary
The importance of forest products to the households who live in or close to the forests has been increasingly recognised over the past ten years. The numbers of people who in some way rely on the forest for survival or livelihood inputs is difficult to assess, and estimates vary widely. The authors of this paper argue that these are not the most appropriate measures of the importance of forests to users, and propose an approach that disaggregates the subject. A typology of different types of users is put forward that recognises the varied nature of relationships of people to forests and forest products, and the impact on them of changes in economic, cultural and social conditions. It is by understanding these patterns of use and change that management can correctly match institutional change to changing patterns of demand, use and supply, and support both "forestdependent" and "forest-related" people in appropriate ways.
\end{abstract}

CENTER FOR INTERNATIONAL FORESTRY RESEARCH

office address: Jalan CIFOR, Situ Gede, Sindangbarang, Bogor 16680, Indonesia mailing address: P.O. Box 6596 JKPWB, Jakarta 10065, Indonesia

tel.: +62 (251) 622622 fax: $+62(251) 622100$

email: cifor@egnet.com

$W W W:$ http://www.cgiar.org/cifor 


\section{The CGIAR System}

The Consultative Group on International Agricultural Research (CGIAR) is an informal association of 41 public and private sector donors that supports a network of sixteen international agricultural research institutes, CIFOR being the newest of these. The Group was established in 1971. The CGIAR Centers are part of a global agricultural research system which endeavour to apply international scientific capacity to solution of the problems of the world's disadvantaged people.

\section{CIFOR}

CIFOR was established under the CGIAR system in response to global concerns about the social, environmental and economic consequences of loss and degradation of forests. It operates through a series of highly decentralised partnerships with key institutions and/or individuals throughout the developing and industrialised worlds. The nature and duration of these partnerships are determined by the specific research problems being addressed. This research agenda is under constant review and is subject to change as the partners recognise new opportunities and problems. 


\section{Contents}

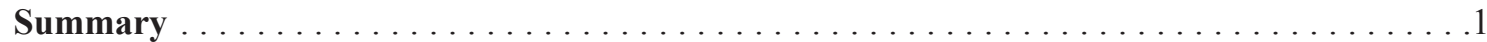

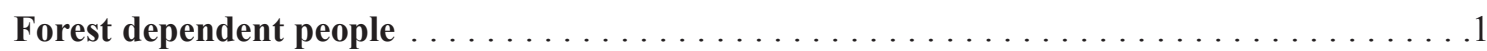

Local important of tropical forests: food, fuel, medicines $\&$ household incomes . . . . . . . . 3

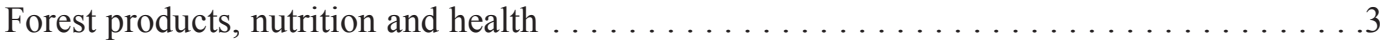

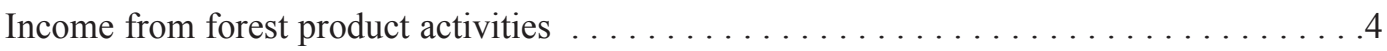

Patterns of change in access to forests and use of forest products $\ldots \ldots \ldots \ldots \ldots \ldots$

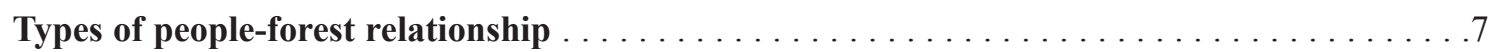

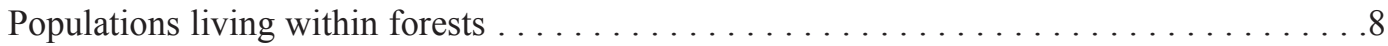

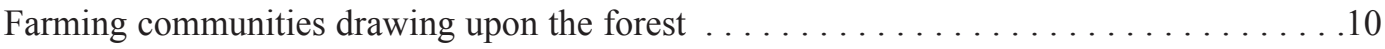

Livelihoods based on commercial forest product activities $\ldots \ldots \ldots \ldots \ldots \ldots \ldots$

What are the development options for forest people? $\ldots \ldots \ldots \ldots \ldots \ldots \ldots \ldots \ldots \ldots$

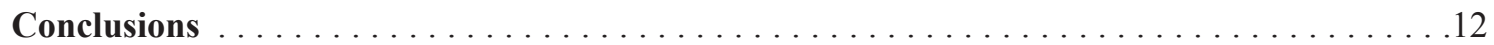

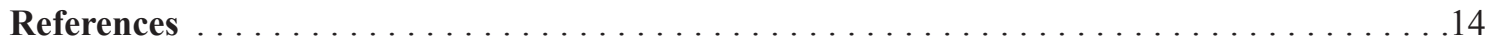




\title{
What Futures for the People of the Tropical Forests?
}

\author{
Neil Byron and Michael Arnold ${ }^{1}$
}

\begin{abstract}
Summary
The importance of forest products to the households who live in or close to the forests has been increasingly recognised over the past ten years. The numbers of people who in some way rely on the forest for survival or livelihood inputs is difficult to assess, and estimates vary widely. The authors of this paper argue that these are not the most appropriate measures of the importance of forests to users, and propose an approach that disaggregates the subject. A typology of different types of users is put forward that recognises the varied nature of relationships of people to forests and forest products, and the impact on them of changes in economic, cultural and social conditions. It is by understanding these patterns of use and change that management can correctly match institutional change to changing patterns of demand, use and supply, and support both "forest-dependent" and "forest-related" people in appropriate ways.
\end{abstract}

\section{FOREST DEPENDENT PEOPLE?}

Over the past decade, environmental and developmental concerns have converged, with the increasing interest in both tropical forests as an important ecosystem, and in the well-being of people who live in or near them. The importance of forests and of Non-Timber Forest Products (NTFP) to the quality of life and even survival of very large numbers of poor rural people in tropical developing countries now seems indisputable (Ruiz Pérez and Arnold 1996).

Yet very great uncertainty persists about who these "forest-dependent people" are, and where they can be found. Estimates of the numbers of people involved range from perhaps 1 million to 250 million (Pimental et al., 1997), to over 500 million (Lynch and Talbot 1992), to over 1 billion (WCFSD 1997). Much of the discrepancy can be explained by the ambiguity (or complete lack) of definitions.

Frequently the estimates of the "numbers of people practising shifting cultivation" have been cited, although this is by no means synonymous with "numbers of people generating much of their livelihood from forests" (Estimates of the number of shifting cultivators suffer from equally confused terminology and absence of rigorous definition). Some studies refer to the number of people who are totally dependant on forests - deriving their entire subsistence from forests, such as hunter gatherers (a definition that, though explicit, is difficult to apply). At the other extreme are estimates which include as "forest dependent" anyone who ever makes any opportunistic use of some product from the forest, or even trees outside forests. For example, Pimental et al. (1997) apparently include all people who collect, use or sell NTFP, the people who harvest cultivated trees from farm lands, even workers on tea estates and banana plantations, as "forest dependent". Lynch and Talbot (1992) estimate the number of people living in or near forest reserves as 500-600 million in Asia alone. However, "proximity to forests" is not synonymous with "forest dependence", although clearly the two are related.

Many urban households, particularly in Africa, rely on fuelwood which they purchase, and there seems no feasible substitute for the foreseeable future. Does this mean that they are "dependent" on the forests from which their supplies come? Similarly many people rely on purchased traditional forest-sourced medicines, for both cultural and price reasons. But that does not necessarily mean that they have a relationship with the forest. Thinking about this type of "commercialconsumer/user dependency" illustrates what a diverse array of situations have been lumped together under this rubric, and that "the line has never been drawn" about which groups are counted in the disparate estimates of forest-dependent peoples. Is it reasonable, or meaningful, to argue that both artisans and crafts-people who use forest products and subsistence hunter-gatherers living in forests, are "forest dependent" - given that their linkages to the forest are clearly so different?

The existing literature is thus quite unsatisfactory for developing an understanding of the types of rela-

\footnotetext{
Respectively, Assistant Director General and Senior Research Fellow, Center for International Forestry Research, Bogor, Indonesia. The authors gratefully acknowledge the valuable comments and suggestions of Bruce Campbell at the University of Zimbabwe, Harare, Bob Fisher at RECOFTC, Bangkok, and Manuel Ruiz Pérez and Lini Wollenberg at CIFOR.
} 
tionships that exist between tropical forests and the people who currently use them, benefit from them and frequently protect and manage them. One purpose of this paper is to elaborate the different contexts in which different types of people depend either on the forests per se, or specific products from them (e.g., medicines, fuel, fodder, craft woods). Even more importantly, we explore the way the people-forest-NTFP relationships are changing over time.

While detailed case studies of specific contexts have been conducted and reported in the literature e.g., an Amazonian tribe living in the forests, collectors and traders of NTFP in West Africa, India or Southeast Asia - many of these studies have only partially documented the relationship between local forest users and the forests they use or depend upon. Even fewer have considered that relationship's future. From a policy perspective, even more important than such a "snapshot" is to understand how these people-forest relationships might change over time, in particular economic, cultural and political contexts. While it is important to know whether there are 100 million or 1000 million people currently actively using forests and forest products, it is even more important to develop a deeper understanding of the relationships and the dynamics.

The condition of "dependence" is defined as "to rely for support" (Webster), or "to be unable to do without" or "need for success" (Oxford). Much use of forest outputs clearly does not carry this connotation. Many users have alternatives, and use forest outputs as a matter of choice, not necessity. But some are dependent in the literal sense that their condition would worsen if they no longer had access to the forest outputs that form an integral part of their livelihood systems.

We argue that there are fundamentally different types of users, which can be summarised crudely as ranging from "those who choose to generate much of their livelihood from forests because it is an attractive, viable option", across a spectrum to "those for whom forest dependency is a livelihood of last resort - a symptom of their limited options and/or poverty - which they will abandon as soon as any plausible option emerges". In many cases, there is also a strong cultural or spiritual element in the people-forest relationships, while in others it is primarily an economic choice (broadly defining economic to include non-monetary benefits.)

Particularly in developing policies that are devolving authority and responsibility for managing forests to local communities, it is crucial to assess whether the number of people willing and able to participate in forest management is likely to increase or decrease or, more realistically, why it might increase in some places while declining rapidly in others. It is extremely important, especially for assessing the impacts of policy reforms, to have a very clear idea of who and where are the affected groups and how might they be affected. Which of them can and most likely will move away from their present levels of forest or NTFP use? Which of them need to continue to be able to draw on forests? What are the implications for policy and management of these very different scenarios?

Another aspect that also has to be addressed is how much of the flows of "forest" products actually comes from forests, as distinct from tree stocks and formations such as bush fallow and farm trees that occur outside the forest? Though our interest here is in people's linkages with forests, many users do not make this distinction, and we therefore need to recognise this continuum between forest and non-forest.

We therefore seek to deconstruct the term and the concept of "forest-dependent people", to expose the great diversity of situations that have previously been lumped together, in order to better understand the current situations and, even more importantly, to recognise the divergent trends which appear to face different groups. We seek to clarify the debate by presenting a series of identifiable categories, illustrated by examples from specific contexts. But we will resist the temptation to undertake a global "head-count" as we believe it is far more important to understand the nature and the importance of the relationships between local forest users/managers and their forests, and then how these relationships might change and adapt over time. Simply adding the numbers of "forest-dependent people" is not very useful and almost certainly soon out of date, even if initially plausible, because of the rapid changes in these relationships which we observe in certain countries. The number of people concerned is not the only, or the best, indicator of the importance of this topic.

Moreover, the basis for making useful estimates of the numbers of people who draw on forest outputs for a specified proportion of their inputs simply does not exist. Relatively few surveys record the numbers of users, especially if much of that use is of a subsistence nature, and even less on the magnitude or value of that use to the users. ${ }^{2}$ Furthermore, the importance of

\footnotetext{
2 As most production, trade and use of forest products for household consumption occurs in the informal sector, much of it outside the market economy, very little is recorded. Most information has to be derived from case studies and special surveys. Even these frequently encounter difficulties in capturing accurate information on household incomes (because of people's widespread reluctance to disclose such information), in providing information about the value of subsistence uses, and in separating out that part of household incomes and costs that is attributable to forest product activities. There are also considerable difficulties in identifying which NTFP supplies come from forests, as distinct from farm bush and other tree formations and stocks outside forests.
} 
household use lies not always in its magnitude, or even its share of total household inputs, but in the way it helps meet particular household needs. The estimates that have been advanced as numbers "dependent" on forests, and the extent of their dependency, are therefore likely to be significantly wrong, and could be very misleading.

In the following section we summarise the diverse ways in which forests are extremely important to particular people in particular contexts, the nature and consequences of the changes in these relationships, and examine measures of importance that are far more informative (but more complex) than simple estimates of "numbers of people generating all or part of their livelihood from forest activities" or living in/near forest reserves. The third section establishes a "typology" to identify the likely importance of forests to different categories of households. The final section considers possible alternative futures - how the different contexts described in the typology might develop in future. We hypothesise that the persistence of viable local management groups will depend greatly on how the different types of people-forest relationships respond to economic, social and political changes which either reinforce or erode people's incentives and capabilities to practise local forest management.

\section{THE LOCAL IMPORTANCE OF TROPICAL FORESTS: FOOD, FUEL, MEDICINES \& HOUSEHOLD INCOMES ${ }^{3}$}

For millions of people living in forest environments, the forest forms such a dominant part of their physical, material, economic and spiritual lives that its importance is not most appropriately described and assessed in terms of the individual products or services that the forest provides. The forest, as well as providing a wealth of material outputs of subsistence or commercial value, is the basis for livelihood systems based on hunting and gathering, or of rotational agriculture systems that depend on the ability of bush fallow to revive the productivity of the land. The forest thus constitutes an integral part of the habitat and of the social and cultural structure of those living within it. It should therefore be assessed and measured in toto, recognising that physical, extractable non-timber forest products are only a limited subset of that whole.

However, a far larger proportion of users of forest outputs live in situations in which they are less intimately linked to forests. Forest products, though important, form a lesser part of the household livelihood system. To understand their relationships to the forest we do need to examine and understand the nature and dynamics of their particular uses of forest products.

\section{Forest products, nutrition and health}

Forests and forest trees are the sources of a variety of foods, that supplement and complement what is obtained from agriculture, of fuels with which to cook food, and of a wide range of medicines and other products that contribute to health and hygiene. Probably the majority of rural households in developing countries, and a large proportion of urban households, depend on plant and animal products of forests to meet some part of their nutritional, cooking and/or health needs.

Forest foods seldom provide the bulk, staple items that people eat. For the majority of rural people, forest foods add variety to diets, improve palatability, and provide essential vitamins, minerals, protein and calories. The quantities consumed may not be great in comparison to the main food staples, but they often form an essential part of people's diets.

Forest foods are most extensively used to help meet dietary shortfalls during particular seasons in the year. Many agricultural communities suffer from seasonal food shortages, which commonly occur at the time of year when stored food supplies have dwindled and harvest new crops is only just beginning. Forest and farm tree products are also valued during the peak agricultural labour period, when less time is available for cooking and people consume more snack foods.

Forests are especially important as a source of foods during emergency periods such as floods, famines, droughts and wars. Often these food resources differ from resources exploited in other periods. In famine periods, roots, tubers, rhizomes and nuts are most sought after. They are characteristically energy rich, but often require lengthy processing.

Supplies of wood fuels influence nutrition through their impact on the availability of cooked food. If there is less fuel (or time) for cooking, consumption of uncooked and reheated food may increase. This may cause a serious rise in disease incidence as few uncooked foods can be properly digested, and cooking is necessary to remove parasites. A decrease in the number of meals provided may have a particularly damaging effect on child nutrition, as children may be unable to consume enough of often an over-starchy staple food in one meal (Cecelski 1987; Falconer 1989).

\footnotetext{
3 This section draws on studies which have synthesised large amounts of material from case studies from ethnobotany, anthropology, geography and other disciplines, on forest product output and use in particular situations (de Beer and McDermott 1989; Falconer and Arnold 1989; Falconer 1990; FAO 1995; Townson 1995a).
} 
Medicinal usage of forest products tends to overlap with that of forest foods; indeed particular items added to foods serve both to improve palatability and act as a health tonic or prophylactic. There are also often strong links between medicinal use and cultural values; for example, where illnesses are thought to be due to spiritual causes, or plants have acquired symbolic importance as treatments.

\section{Income from forest product activities}

Very large numbers of households also generate some of their income from selling forest products. Most such commercial forest product activities are conducted part-time by farm households which cannot raise enough to be food self-sufficient year round. For most users, the importance of forest products income is usually more in the way it fills gaps and complements other income, than in its absolute magnitude or share of overall household income. ${ }^{4}$

Income-earning activities based on marketable forest products may be seasonal or year-round, or may be occasional when supplementary cash income is needed. There are several dimensions to the seasonality of forest-based income-generating activities. Some are governed by seasonally induced cash needs, such as the need for income to buy food during the "hunger period" between harvests, or to purchase farm inputs. Other activities are seasonal largely because the crop or material can only be gathered at certain times of year. The fluctuation in timing of other forest product activities is dictated by the seasonality of other activities, such as demand for baskets needed at harvest time, and the surge in demand for many items as agricultural incomes peak. Some activities are also linked to fluctuations in availability of labour, and decline in agricultural and planting seasons, or are phased to take advantage of slack periods. Often these pressures work in conjunction one with another, within sequences in which one activity's output becomes another's input e.g., generating income from forest products in order to purchase seeds, hire labour for cultivation or generate working capital for trading activities (Leach and Fairhead 1994). Forest products can also provide a source of "windfall" income; a good crop providing a valuable injection of cash, enabling people to clear their debts or accumulate some capital (de Beer and McDermott 1989).
Forest product activities also can provide an important supplemental source of income that people can fall back on in times of crop failure or shortfall, or in order to cope with some other form of emergency. Forests are therefore often very important as an economic buffer and safety net for poor households.

Where people have had relatively unrestricted access to forests, forest foods and forest products income are often particularly important for poorer groups within the community. Though it is often the wealthier in a community, with more resources to devote to forest gathering and production, who are the heaviest users (Madge 1990; Cavendish 1996; Ogle 1996), the poor usually derive a greater share of their overall needs from forest products and activities (Belsky 1985; Fernandes et al. 1988; Hecht et al. 1988; Siebert and Jodha 1990; Gunatilake et al. 1993). The characteristics of easy access to the resource and low entry thresholds enable many women to generate income from forest products activities. Such activities are often an important source of the income that women need to meet the costs of feeding and clothing the family, and they can be more dependent on such income than men (e.g., Hopkins et al. 1994).

In short, if we are to arrive at meaningful estimates of the importance of forests and forest products to people in their vicinity, we need to focus on measures that reflect the diversity of situation that exists, and the fact that for most this importance is best expressed in qualitative rather than quantitative terms. To do otherwise could prove to be very misleading. In the one region in which household survey results over large areas and populations do give us some basis for estimating numbers of people involved, Africa south of the Sahara, it appears that roughly 15 million people, about 4 per cent of the rural population, obtain some of their income from forest products. As there are generally only one or two members of a household engaged in these activities, this could mean that 60 to 70 million people are living in households that could benefit from this income.

Only a small proportion of this number is living in or adjacent to forests; most are in more sparsely wooded parts of the region, and much of their supply of "forest" products comes from outside forests. In one of the surveys of a population in a forest zone, in southern Ghana, where 10 per cent of the population were generating some income from forest product activities,

\footnotetext{
4 Information about the magnitude and role of forest product income in the household is weak, reflecting difficulties encountered in eliciting accurate information about household income, and the fact that a forest-based activity usually constitutes just one activity within an agricultural household. It then becomes difficult to separate out the part of household time, costs, returns, etc., that is attributable just to that activity. In addition, very few studies exist that identify how household income from forest product activities is spent.
} 
only a minority of those involved reported that it was a major source. But more than 70 per cent stated that it was important in helping them meet particular needs, or because of its timing, or in absolute terms (Townson 1995b).

To focus on numbers of people directly obtaining income from forests would therefore, at least in Africa, lead us to conclude that this involves a rather small share of the rural population. ${ }^{5}$ To narrow our concern down just to those who obtain the greater part of their inputs from forest products, would diminish our target population much further. The dangers of adopting this approach become even more evident when we look at how the relationships between people and forests are changing.

\section{Patterns of change in access to forests and use of forest products}

\section{Changes in subsistence use}

In some situations subsistence use of forest products appears to be dwindling, as people rely to a greater extent on food purchasing, as famine relief programmes become more effective, or as improved supplies of food crops have diminished the need to depend on forest foods. In Vanuatu, for instance, the introduction of the sweet potato, which can be planted at any time and produce an edible crop within three months, and manioc, which can be left unharvested for up to two years, has made the traditional emergency foods of wild taro, arrowroot, wild yams and sago virtually obsolete (Olsson 1991).

Other changes that reduce the role that forest food plays in household nutrition may reflect penetration of rural markets by new food products, changing tastes or decreased availability. However, the latter may reflect changes in the availability or allocation of a household's supply of labour rather than physical shortage of the product. As the pressures on women's time increase they may no longer have as much time for gathering forest foods. As the value of labour rises with increasing wealth, the opportunity cost of continuing to spend time gathering foods, rather than purchasing them, becomes increasingly unattractive.

A decline in use of forest food can also reflect reduced knowledge about its use. As children spend more time in school than in the fields and the bush, the opportunity to learn about which plants can be consumed, and which cannot, is reduced. Sedentarisation is another widespread change that distances people from the food sources they used to be familiar with, constraining people's use of these foods even when they are still available and important for dietary balance (Melnyk 1993).

However, a frequent cause of reduced subsistence use is likely to be shortages. These may be physical shortages due to over-use, shortages due to increasing restrictions on access to supplies, or economic shortages due to rising costs or/and growing competition for supplies. The needs of the poor for income from forest product activities can result in the diversion of supplies from own consumption to the market. A recent village study in Vietnam, for instance, found that forest vegetables, bamboo shoots and mushrooms that were collected and eaten by wealthier households, had to be sold in poorer households in order to be able to buy rice (Nguyen Thi Yen et al. 1994).

Some changes in subsistence use therefore reflect choice; part of the process of evolution to a different livelihood level in which forest inputs have a lesser role. Some are responses to pressures that make it less possible for the household to maintain the same level of use. Nevertheless, it is clear that in general subsistence use continues to be very large, even where people are becoming increasingly integrated into the market economy. Also, the buffer role of the forest - as a food and fodder resource that enables people to survive periods of agricultural shortfalls - continues to be very important for many people (Falconer 1994; Ogle 1996).

\section{Patterns of change in income-generating activities}

In some situations households are becoming more reliant on income from tree product activities, while in others they are moving away from involvement. At the same time, some kinds of forest product activities are expanding while others are stagnating or declining. If we are to understand where access to forest outputs is likely to be important in the future, it will be necessary to be able to identify and understand these differential patterns of change.

\section{Market factors}

The level of output in some activities is changing because of the nature of the markets into which the product is sold. Though some products have large, diversified and stable markets, others face highly

\footnotetext{
Much of forest products employment in Africa is in activities of "last resort", reflecting the extreme poverty, stagnation of agriculture and lack of alternatives in the rural areas of that region. As such conditions are not widespread in the other two regions, it seems unlikely that they would exhibit such high densities of forest product involvement as is found in Africa, except in more remote parts of the Indian sub-continent, Indochina and inland China.
} 
volatile markets, or demand that is seasonal and subject to sharp price fluctuations. Production of some of the "extractive" products for industrial markets, for instance, is susceptible to major changes in market requirements, and to shifts to domesticated or synthetic sources of supply (May et al. 1985; Afsah 1992; Browder 1992; Homma 1996).

Domestic markets for forest products may provide more stable avenues for development. The large component of forest products activities in the rural sector reflects the size of rural markets for these products, and their dispersion across large areas with a relatively poor transport infrastructure, so that they are more effectively supplied locally (FAO 1987). Increasingly it also reflects demand from growing urban populations for some of these products. In many countries the domestic product trades are much larger, involve many more people, and are likely to develop in less disruptive ways than trade in products serving external markets. In Ghana, for instance, a national household survey in 1992 found that even in the city of Accra more than three-quarters of all households purchased one or more of five forest products; ${ }^{6}$ with as high or higher proportions of purchasers recorded in the rest of the country (Townson 1995).

However, some forest products used domestically are "inferior goods" that fall out of consumption patterns as incomes rise - some forest foods being displaced by more convenient purchased foods for example. Others, such as mats, are vulnerable to competition from factorymade alternatives as improved transport infrastructure opens up rural areas to outside supplies. But demand for other ("normal" or "luxury") goods rises with prosperity. The market prospects for products will also differ according to the phase of the market cycle they are in - i.e., are these emergent, expanding, mature or declining markets?

\section{Production factors}

The evolution of some activities is conditioned by the fact that features of their production or distribution process enable or prevent the component enterprises increasing in size, or adding extra value by diversifying into additional stages of the process, or organising the process more efficiently. For example, such factors seem to contribute to the finding in small enterprise surveys in eastern and southern Africa that employment in woodworking has been growing ten times faster than employment in mat and basket making activities (Arnold et al. 1994).

Other reasons for growth or decline are to be found within the individual enterprise. The opportunities to generate income from expanding forest product activities may require managerial or particular technical skills, or access to capital or credit, and will therefore be available only to some. Despite the importance of such activities to the poor, they are therefore less likely than wealthy neighbours, or outsiders, to be able to exploit the opportunities that new or upgraded markets present. This is of particular importance given the concentration of poor households in forest output activities.

Another powerful factor is the availability, and relative attractiveness, of alternative ways of earning income. Many forest product activities are time consuming, often tedious and arduous, and generate very low returns. They are consequently likely to be abandoned once more rewarding and congenial alternatives become available, or as increasing pressures on household labour resources make such low value labour intensive activities no longer competitive. Others are likely to be attractive only temporarily, for example, wood fuel production and sales by immigrants or young men in the process of clearing land in order to create their own farms.

\section{Access to forests}

Access to a usable resource is of course another major factor. Problems of selective over-use, resulting in rising costs and values of sought after species and products (Homma 1996; Wilkie and Godoy 1996), are frequently aggravated by measures that alienate the resource to the state or result in de facto privatisation by the wealthier and more powerful of the users. Many users are progressively restricted in their choice to resources available in bush fallow and farm bush on lands over which they have some measure of individual control and to resources they can create by growing trees on their farms.

Tree management decisions by farmers reflect much more than just diminishing stocks of naturally occurring tree stocks. Historically, the place of trees on farms has usually been shaped primarily by growing pressures on limited amounts of arable land. However, as farm households have increasingly to depend on income earned from employment off-farm, labour rather than land is widely becoming the main resource limitation determining farmer options. Because the growing of trees requires lower inputs of labour to establish and maintain than most other crops, such shifts in the ratio of labour to land can encourage greater reliance on tree crops, in a number of different circumstances. In many places, the focus of rural households' supply of some "forest" products is steadily shifting from the forest to the farm.

\footnotetext{
6 In order of importance by value: wood fuels, palm wine and spirit distilled from palm wine, bushmeat, snails, furniture and shea butter (Townson 1995b).
} 
However, this shift is only possible for those who have access to land, and sufficient resources to work the land. Reduced access to forest sources of the products they need is consequently often reducing the ability of small farmers, landless households, and others among the poor to continue to participate in forest output activities. In addition, farm trees can provide only some of the outputs that people previously obtained from forests; they are therefore not a full substitute for the latter.

\section{Re-assessing "forest dependency"}

To summarise, a very large share of rural populations, and many urban households, in developing countries still include one or more forest or tree foods in their diets, cook their food using wood fuels, and rely on traditional medicines from plant and animal products. Though the share of such products in overall nutrition and health may often be declining, and supplies are increasingly coming from managed tree stocks rather than natural forests, ${ }^{7}$ the numbers of users may be expanding. Tens of millions of people also generate some of their income from forest products; and the importance of this clearly is growing.

Some of these changes reflect shifts in consumption patterns and habits, and the emergence of more productive or attractive options, as economies grow and incomes rise. Others are changes enforced by competition, rising costs and declining availability. With such diversity of situation, it is difficult, and could be misleading, to try and draw conclusions of general application. This is all the more so because of the wide variation in needs and use of forest outputs within most situations between richer and poorer within a community, and within a household between men and women, and even between age groups.

Nevertheless, some general patterns can be discerned. In situations where population is growing faster than per capita incomes, forest product activities emerge largely to absorb people unable to obtain income, or sufficient income, from agriculture or wage employment. This situation is likely to be characterised by labour-intensive, low-return, typically household- based, activities such as collecting and mat making.

In situations where per capita incomes are rising, growth is more likely to be demand-driven, and lowreturn, labour-intensive activities tend to give way to more productive and remunerative activities such as vending, trading and activities to meet growing and diversifying rural demands. At that stage, production and selling of forest products increasingly shifts from a part-time activity by very large numbers of people to more specialised year-round operations by a smaller share of the population (Haggblade and Liedholm 1991; Liedholm and Mead 1993).

Over time, therefore, we can expect some forest products to become increasingly important. Others, in contrast, will fall out of use, and cause some forest product activities to become redundant and decline. In particular, those that generate only marginal returns to those engaged in their harvest and sale are unlikely to survive as costs rise and competition intensifies, or will persist only as long as the participants have no better option.

This shift is complicated by the fact that forests and forest product activities often play an important buffer role during the process of growth and change; a source of products and income that people can fall back on temporarily if need be. It therefore cannot be assumed, as people's use of forest products diminishes, that this necessarily removes the "safety net" role of the forest.

These complex relationships cannot be assessed by uni-dimensional criteria, and cannot be merely described as "forest dependency" without a serious loss of important information. In the following section we attempt a typology of these relationships in which people use and rely on the forests, and the reciprocal side of the relationship - what each group puts back into the forests, in terms of their protection and management. Then we can consider the forces for change in people's use of the forests, and consider the implications of such changes for the question of: who will manage the forests, for what purposes? In preparing for the devolution of decision-making and responsibility for forest stewardship to local forest-based communities, it will be essential to assess, for each specific context, the continuing interest, willingness and capacity to protect and manage forests, as the available set of socio-economic alternatives expands with development.

\section{TYPES OF PEOPLE-FOREST RELATIONSHIPS}

In this section we propose a typology of different kinds of users, identify for each type the nature of the relationship to forests and forest outputs, the importance of the forest outputs in the livelihood system in question, and the likely impacts of change. There are several dimensions of such a typology, reflecting different aspects of their role and importance:

\footnotetext{
A study in a forested area in Sierra Leone, for instance, found that only 14 per cent of all hunted or collected foodstuffs derived from the forest itself, and 32 per cent of the medicinal plants (Davies and Richards 1991).
} 
- Participation in forest output activities: reflecting the frequency or timing of use of forest products, and the extent to which household labour is allocated to these activities.

- Role of forest products in household livelihood systems: their importance as a share of household inputs, and in meeting household livelihood strategy objectives.

- Impact of reduced access to forests: does the forest serve as a [critical] economic and ecological buffer for its users, or are their alternatives, such as trees outside the forests or non-forest/tree sources of needed inputs and income?

- Likely future importance of forest outputs: do users face a growing or declining demand for forest outputs; or the potential for expanded or decreased involvement in production and trade in forest products (relative to alternatives)?

These are broken down and spelled out in more detail in Table 1. They underlie the assessment set out below of a number of broad types of people-forest situations. The first covers populations living within a forest environment; principally hunter-gatherers and those practising long-rotation shifting cultivation. The second encompasses populations in a predominantly agricultural landscape, and practising livelihood systems in which they continue to rely on being able to draw on adjacent areas of forest and woodland to supplement what they can produce on farm. The third includes people and households who draw on forests indirectly, e.g., as traders, further processors, employees, etc. and are not necessarily living in or near forests.

There are not clear cut boundaries either between or within these component parts of the whole. For instance, at the edges of forests shifting cultivation grades gradually into rotational agriculture. Similarly, the agriculture-plus-forest-input category ranges all the way from rotational bush fallow subsistence agriculture to predominantly commercial agriculture systems. Equally importantly, there is often a wide range of different levels and patterns of people-forest relationship even within a single situation. Nevertheless, such a framework does help in capturing some of the salient features of the variation in people-forest relationships.

\section{Populations living within forests}

\section{Hunters and gatherers}

Forests provide the main sources of livelihood, and are usually of very great cultural importance. Any change in the extent and quality of the forest, or in access to traditional forest areas, is likely to be very disruptive of traditional use and activity patterns.

Some populations (e.g., in parts of the Amazon basin (Grenand and Grenand 1996)) have managed to retain predominantly subsistence and self-reliant ways of life. Most, however, are increasingly affected by exposure to market forces. Where this is the case they tend to be highly dependent on middlemen for access to outside markets for sale of their products, and for supplies of outside goods (Peluso 1986; Afseh 1992; Browder 1992). Despite romantic notions of "affluent subsistence" life is typically tough and short, with generally low returns per effort expended.

The direction and impacts of change are likely to be very variable. When exposed to external pressures and opportunities (e.g., from logging companies), some indigenous peoples are assimilated, others cling to traditional ways, while others (such as Dayaks in Malaysian and Indonesian Borneo) seek to find a middle road - to adapt to and absorb what suits them from modern industry and society, while retaining traditional cultural and social values, by alternating between the forest village and the industrial workplace.

\section{Shifting cultivators}

The forest forms the starting point for crop agriculture in areas of cleared forest, alternating with long periods of forest fallow. Such shifting cultivation is supplemented by gathering and hunting inputs from the forest, and from the bush fallow. The cultural importance of the forest is typically very strong.

Any decline in the forest area available for the system, typically because of alienation by the state, encroachment or/and increasing population pressure, is likely to lead to shortened fallow periods, declining productivity, progressive degradation of remaining forest, and increasing reliance on fallow and farm as the source of "forest" products. Exposure to the needs and opportunities to earn income from outside wage employment can also diminish the availability of the labour needed to sustain the system, causing the abandonment of low-value labour-intensive forest product gathering activities.

Shifting cultivation systems, like hunting and gathering, consequently seldom provide a basis for livelihood improvement and they are often difficult to sustain, even at present levels. Both are likely to decline as expanding rural infrastructure improves the prospects for more intensive agriculture and wage employment. However, increasing market opportunities and pressures may enable people to stabilise their situation by shifting to agro-forest systems that provide more productive use of the forest area remaining available to them (e.g., durian gardens in West Kalimantan (Peluso and Padoch 1996)). 
Table 1. Some sets of criteria for assessing the importance of/degree of reliance on forest outputs (with illustrative examples)

\begin{tabular}{|c|c|c|}
\hline Criterion & Indicator & Example \\
\hline \multirow{4}{*}{$\begin{array}{l}\text { PARTICIPATION IN } \\
\text { FOREST OUTPUT } \\
\text { ACTIVITY } \\
\text { (labour allocation) }\end{array}$} & Year round & $\begin{array}{l}\text { Full time activity (e.g., carpenter, trader, employee) or continuous } \\
\text { part-time component of household activities }\end{array}$ \\
\hline & Periodic & To fill seasonal gaps or to exploit seasonal availability \\
\hline & Temporary & By new farmers establishing farms \\
\hline & Occasional & A buffer in hard times, meeting one-off costs (e.g., marriages) \\
\hline \multirow{5}{*}{$\begin{array}{l}\text { ROLE IN } \\
\text { LIVELIHOOD } \\
\text { SYSTEMS }\end{array}$} & $\begin{array}{l}\text { Central- } \\
\text { fundamental }\end{array}$ & $\begin{array}{l}\text { Forest-dwelling hunter-gatherer and subsistence (true shifting } \\
\text { cultivation) populations }\end{array}$ \\
\hline & $\begin{array}{l}\text { Major } \\
\text { important }\end{array}$ & $\begin{array}{l}\text { Substantial share of household inputs; important supplementary } \\
\text { role (seasonal income, dietary inputs); basis for livelihood } \\
\text { enhancement (e.g., more profitable activity) }\end{array}$ \\
\hline & $\begin{array}{l}\text { Minor but } \\
\text { significant }\end{array}$ & $\begin{array}{l}\text { Improves palatability of diets; opportunities/windfall source } \\
\text { of inputs/income }\end{array}$ \\
\hline & Risk limitation & $\begin{array}{l}\text { Subsistence and economic buffer in hard times; "safety net/last } \\
\text { resort" source of income; diversifies household input base }\end{array}$ \\
\hline & Declining & $\begin{array}{l}\text { Items falling out of household consumption patterns; } \\
\text { unprofitable activities being abandoned as better alternatives } \\
\text { become available }\end{array}$ \\
\hline \multirow{4}{*}{$\begin{array}{l}\text { IMPACT OF } \\
\text { REDUCED ACCESS } \\
\text { TO FORESTS }\end{array}$} & Critical & (threatens the existence of a community in its present form) \\
\hline & Severe & $\begin{array}{l}\text { (causes serious worsening of livelihood situation at least } \\
\text { temporarily) e.g., forest foods, income, in time of extended } \\
\text { drought or other calamity time/major activity based on forest raw } \\
\text { material }\end{array}$ \\
\hline & $\begin{array}{l}\text { Modest } \\
\text { (transitional) }\end{array}$ & $\begin{array}{l}\text { can switch to source outside forest (bush fallow, etc.) or can } \\
\text { switch activity/product }\end{array}$ \\
\hline & Minimal/none & $\begin{array}{l}\text { (users already moving away from involvement with forest } \\
\text { products) e.g., no longer competitive or better } \\
\text { alternatives now available }\end{array}$ \\
\hline \multirow[t]{4}{*}{$\begin{array}{l}\text { LIKELY FUTURE } \\
\text { IMPORTANCE OF } \\
\text { FOREST OUTPUTS }\end{array}$} & Could increase & $\begin{array}{l}\text { (or at least stay as important as at present) due to no better } \\
\text { options (for income, low skill, stagnant economy) or } \\
\text { depletion of non-forest raw material "dependence" on forest } \\
\text { products }\end{array}$ \\
\hline & $\begin{array}{l}\text { Changes in } \\
\text { structure; use } \\
\text { concentrated } \\
\text { on fewer } \\
\text { products }\end{array}$ & $\begin{array}{l}\text { growth in use of selected products (providing opportunities } \\
\text { for using others; or domesticated and non-forest } \\
\text { resources become more important }\end{array}$ \\
\hline & $\begin{array}{l}\text { Declining, but } \\
\text { still important } \\
\text { as buffer }\end{array}$ & $\begin{array}{l}\text { in earlier still unstable stages of evolution to a higher income, } \\
\text { more as emergency relief/avoidance measures } \\
\text { still not adequate. }\end{array}$ \\
\hline & Not important & $\begin{array}{l}\text { users phasing out (most) forest product activities, due to no } \\
\text { remaining demand for many forest products; forest } \\
\text { sources no longer competitive; domesticated sources } \\
\text { or substitutes; or better livelihood alternatives. }\end{array}$ \\
\hline
\end{tabular}




\section{Farming communities drawing upon the forest}

Off-farm forest/woodland is drawn upon for inputs that cannot be produced on-farm, or that can be more efficiently supplied from off-farm resources. This reliance is likely to increase when crop yields have been poor, and other sources of income are not available. Increasing exposure to market forces, the access to new markets and new technology that this brings, and the growing internal differentiation within communities that usually follows, can have sharply different impacts on people-forest relationships for different groups within a rural community.

Wealthier farmers and landowners may be substantial users of forest outputs (e.g., fodder). With greater access to labour and capital, they are also usually in a better position to exploit new or expanded market opportunities for forest products as these arise. There are numerous recorded instances of economic or political elites within rural communities restricting the access of poorer members to previously communally available forest resources as the market value of the latter becomes more attractive (e.g., Fernandes et al. 1988). Those with sufficient land, and other income, are also better able to create their own resource of planted trees. The wealthier are also more likely to want to exploit opportunities that new markets and agricultural technologies provide to change the use of land previously under forest or woodland (e.g., Jodha 1990).

Poor farmers and landless families, on the other hand, are likely to continue to rely on being able to draw on nearby forests or woodland. Indeed, their reliance will tend to increase as smaller in farm size or declining farm productivity reduce farmers' food self-sufficiency. As this happens, their dependence on forest products as a source of income may increase to the point at which some have to sell products that previously they collected for their own use. The poor and landless are also the people for whom the role of the forest as a buffer on which they can draw in times of hardship is particularly important. At the same time, increasing pressures to take wage employment, in order to meet income needs, are likely to mean that they have less time for labour intensive forest product activities, and so become less able to exploit forest product opportunities.

Increasing conflicts consequently often arise between those able and wanting to privatise communal land and resources, and those who continue to need to have access to such resources. This has contributed centrally to the decline of historical collective management systems, and of the resources controlled in this way, and to the difficulties encountered in creating viable contemporary systems (Arnold and Stewart 1991; Shepherd 1992; Davis and Wali 1993). In short, communities made up of component groups with widely different needs, interests and power find it very difficult to agree on how to manage a local forest resource.

A fundamental feature of many situations is thus that it is the poor who would benefit most from being able to continue to draw on forest products, but they are often faced with a diminishing resource and a declining capacity to exploit it. This contributes to the factors - increasing cost and opportunity cost, and declining markets and competitiveness - that often result in forest product activities playing a reduced role in their livelihood systems.

\section{Livelihoods based on commercial forest product activities}

Artisans, traders and small enterprise entrepreneurs. Much production, processing and sale of forest products occurs as a part-time activity within farming households. Activities such mats, baskets and wood fuel vending, which have low skill and capital thresholds of entry, figure prominently among non-farm commercial activities in which the rural poor engage in the absence of other employment opportunities (Fisseha 1987; Liedholm and Mead 1993).

For those products for which rural and urban markets grow, processing tends to shift from artisans working part-time from the home to a more full-time workshop basis. Both production and trading also tend to become located in larger rural settlements and towns. With this increasing specialisation and concentration, some products previously traded by households get progressively taken over by outside traders and entrepreneurs.

A growing share of the numbers involved in forest product activities are thus outside the forest - for instance, in areas surveyed in southern and eastern Africa, 14 per cent of all those processing and selling forest products were located in urban areas (Arnold et al. 1994). As these are mainly full-time activities, their association with forest products is strong, but at least one stage removed from the forest. For instance, most of those in carpentry and woodworking, even in rural areas, are likely to acquire their wood raw materials through the timber trade rather than from the forest. While they are likely to be affected by decline in supplies, they are likely to have the resources to be able to shift to other sources, other products or other locations. ${ }^{8}$

\footnotetext{
Thus, the African surveys showed that, although there were high rates of closure among small forest product enterprises, nearly one-half of the entrepreneurs involved started new enterprises - some in forest products, most in non-forest product activities (Arnold et al. 1994).
} 


\section{Employees in forest industries}

By far the greater share of those who obtain employment in forest industry activities are in the small enterprises discussed above, rather than in the formal sector. ${ }^{9}$ But these are typically very small, averaging less than two persons per enterprise wherever information on their size exists (Fisseha 1987; Townson 1995a). The bulk of those engaged are thus the entrepreneurs and members of their families.

Where larger, modern-sector, forest industries have become established, they can provide a wage employment alternative to local people previously cut off from such options, and enable them to reduce their reliance on more arduous and less rewarding forest product and shifting cultivation activities. However, many forest industry jobs tend to go to outsiders because of the skills required. Also, employment in logging and primary processing in a particular area tends to be relatively short term - they can be classical "boom-and-bust" activities. The employment and income they provide for a while needs to be set against the disruption of existing livelihood systems in forest areas that they can cause.

\section{WHAT ARE THE DEVELOPMENT OPTIONS FOR FOREST PEOPLE?}

Thus far we have recognised that there are hundreds of millions of people drawing on products of forests, or trees outside forests, to varying degrees, with different degrees of freedom to choose. Even where the quantity of forest products used is small or infrequent, lack of access to forests can cause severe hardships in emergency conditions.

This may be interpreted as a reflection of the poverty and marginalisation of many of the people involved - who have few buffers or safety nets but the forest. We have also noted that, though access to forest products is so widely important in enabling people to survive in a situation of poverty, this set of activities may be less important in helping people escape from poverty. Many are arduous, labour intensive and less rewarding than alternatives that become available as forest regions are opened up. And, because of their poverty, the poor are often not in a position to take advantage of those growth opportunities that some forest products activities do provide.

Another key point that has emerged is that "forest" products are increasingly coming from sources other than forest - bush fallow, farm trees and other tree stocks outside forests as normally defined. Though the purpose of this paper has been to examine just the extent of people's dependence on forests, it is clear that we can only understand the role of forests in meeting people's needs if we recognise this continuum. On occasion management may most appropriately take the form of transforming forest into some form of "agroforest", or creating resources with some of the attributes of forests within agricultural systems - home gardens, compound farms, farm woodlots, etc.

The essential question for any government or development agency anxious to help those called "forest-dependent people" is: what would one do? Firstly, we would argue strongly that there is no general panacea or formula, but rather that a detailed assessment needs to be prepared, by (or at least with) those people concerned. This assessment would cover the complete range of the relationships between the people and the forests which they use and/or manage, the current limitations to their livelihoods, and the potentials and desire for change. However, a number of broad, overlapping, types of situation can be identified:

- forests continue to be central to livelihood systems: local people are or should be the principal stakeholders in these forest areas; meeting their needs is likely to be the principal objective of forest management, and this should be reflected in control and tenure arrangements which are centred on them.

- forest products play an important supplementary and safety net role: users need security of access to the resources from which they source these products, but are often not the only users in that forest area; forest management and control is likely to be best based on resource-sharing arrangements among several stakeholder groups.

- forest products play an important role but are more effectively supplied from non-forest sources: management of forests needs to be geared towards agro-forest structures; control and tenure need to be consistent with the individual (private) rather than collective (common property) forms of governance that this shift is likely to require (Peluso and Padoch 1996).

- $\quad$ participants need help in exploiting opportunities to increase the benefits they obtain from forest product activities: constraints in the way of smallholder access to markets need to be removed (Dewees and Scherr 1995); improved access to

\footnotetext{
9 For instance, the estimate from a national small enterprise survey of 237,000 persons employed in small woodworking, carving, wood fuel and cane and grass products enterprises in Zimbabwe in 1991 compares with a reported 16,000 employed in forestry and forest industries in the country in that year (Arnold et al. 1994).
} 
credit, skills, marketing services, etc., may be required (Liedholm and Mead 1993).

- $\quad$ participants need help in moving out of dead-end forest product activities: helping provide them with new options, which are quite likely to be outside forestry.

This wide range of variation in the situation of people who draw upon forests and forest products, clearly needs to be matched by a selective approach to intervention and support. Whereas for the first category secure tenure, control over access and use, and management responsibility over the forests, constitute necessary and sufficient conditions for the continuing well-being of both the people and the forest, for the second category this is less likely to be the best solution and for the third category it could be unhelpful and possibly unworkable. And for those in the fifth category, their future may not be in the forests at all.

As situations are moving between these categories, often quite rapidly, it is also very important that we do not put in place, or encourage, institutional arrangements which, while they may be relevant at present, are likely to be inconsistent with changes that are taking place, or are likely to take place. For instance, does devolution of responsibility for forest management to local communities make sense in those circumstances where the role of forest products is likely to decline? What would happen to control and management of forests if the former users' interest in forest products, and their time available for forest management and protection, declines after responsibility has been effectively transferred from the state to them?

Similar considerations arise over the more technical aspects of interventions to support people to optimise benefits from the forests they draw upon. In designing programmes to provide support to small forest product activities, it is important to recognise that there are different potential target groups with different needs and opportunities. Those in the process of starting up face different problems and constraints than those seeking to expand. New entrants driven by supply side forces, as people search for activities where they can sustain themselves, face different issues than those who are responding to market opportunities. Among those enterprises that are growing, those seeking to expand from a one-person beginning have different needs for assistance from those that aspire to graduate to larger scales of operation.

Particular issues arise in trying to help the very large numbers of people engaged in low-return forest and tree product activities that can offer no more than marginal, unsustainable livelihoods, presents particular issues. Support to such activities once higher return or less arduous alternatives emerge could impede the emergence of better livelihood systems for the partici- pants. That being the case, it may be more fruitful to help people move into other more rewarding fields of endeavour rather than seeking to raise their productivity in their current activities. Care needs to be taken in such a case to ensure that not only current income levels but also future growth prospects are indeed better in the alternative product lines to which people are being encouraged to move (Liedholm and Mead 1993, Arnold et al. 1994).

\section{CONCLUSIONS}

Huge numbers of people draw upon forest products, or similar products from tree cover outside forests, to meet part of their subsistence and income needs. However, the importance of this people-forest relationship is not best measured or understood through attempts to estimate the numbers of people who "depend" on forest outputs for a specified share of their livelihood inputs. Even if the data existed on which one could base sound estimates of this sort, and it does not, such a focus would fail to recognise that the importance of many of these product and income flows lies in their timing and quality in terms of the livelihood strategy of the household in question, not in their magnitude.

In seeking to establish more useful ways of assessing the significance of people's use of, and reliance on, the outputs of forests and trees, a number of other fundamental factors need to be taken into account. One is the need to distinguish between those uses which do reflect actual dependency on the forest, in the sense that the users would be left seriously worse off in their absence, and those uses which reflect choice, and the presence of adequate alternatives. Much of what gets included in most estimates of "forest-dependent people" is actually choice. Failure to recognise and clarify this can make it more difficult to focus on the problems of the main group of people who are dependent namely the large numbers who are involved in lowinput low-output forest product activities because they simply do not have alternative ways of generating income.

A second factor that has major implications is the impact of change on the different categories of user. It is becoming increasingly clear that, as we would expect from related economic theory (Godoy, Homma 1996), increasing integration into market systems, and the resulting opportunities to meet some needs from imports rather than local production, and to generate income by exporting other products previously consumed locally, can materially and rapidly alter patterns of forest product use. Activities based on low value, labour-intensive forest products and processes will usually decline, while those based on higher valued products in demand in the markets should increase. 
Information about the patterns of use that we are observing in the present, that are usually dominated by low-value products, is therefore likely to be of only limited usefulness in identifying what demands people will make on the forest in the future. Clearly this has major implications for the kind of institutional, support and management interventions that might be needed and appropriate.

Another important aspect that bears on how we adapt forest management to future local needs, is the shift in the focus of production of many "forest" products to bush fallow, trees on farms and other categories of tree cover and tree stocks outside the forest. Managing natural resources to supply "forest" products may in some situations need to focus more on these "agro-forest" systems than on forests. However, this argument needs to be qualified to take account of the continuing role of the forest as a buffer. Some of those who are moving away from stagnant minimal levels of livelihood, as better alternatives emerge and their incomes rise, will continue to need the forest as a buffer to fall back on temporarily in times of hardship. An important challenge is likely to be learning how to manage forests both for growth, and also as a safety net.

A final factor, following on from the others, is that of correctly matching institutional arrangements to these changing patterns of demand, use and supply. In what ways will a sharp decline in local uses of forest products, and trends towards individualisation rather than collective local control of tree resources, affect the present thrust for governments to "hand back" forest management to local people, or at the very least to give them a decisive voice in management decisions and practices? Will "models" for local participation in decision making that rest on local collective institutions still make sense in these situations? There can be no uniform answers to such a question, but the variety of situations that is evolving will surely require a considerable degree of choice and flexibility in developing appropriate institutional arrangements. 


\section{REFERENCES}

Afsah, S. 1992. Extractive Reserves: Economic-environmental Issues and Marketing Strategies for Non-timber Forest Products. ENVAP, The World Bank, Washington (draft).

Arnold, J.E.M. and W.C. Stewart. 1991. Common Property Resource Management in India. Tropical Forestry Paper No. 24. OFI, Oxford.

Arnold, J.E.M., Liedholm, C., Mead, D., and I.M. Townson. 1994. Structure and Growth of Small Enterprises using Forest Products in Southern and eastern Africa. O.F.I Occasional Papers No 47, Oxford Forestry Institute, Oxford and GEMINI Working Paper No. 48, Growth and Equity through Micro-enterprise Investments and Institutions, Bethesda.

Browder, J.O. 1992. The limits of extractivism: tropical forest strategies beyond extractive reserves. Bioscience 42: 174- 182.

Cavendish, W.P. 1996. Environmental resources and rural household welfare. Mimeo. Centre for the Study of African Economies, University of Oxford.

Cecelski, E. 1987. Energy and rural women's work: crisis, response and policy alternatives. International Labour Review 12: 41-64.

Davies, A.G. and P. Richards. 1991. Rain Forest in Mende Life: Resources and Subsistence Strategies in Rural Communities around the Gola North Forest Reserve (Sierra Leone). A report to ESCOR, UK Overseas Development Administration.

Davis, S.H. and Alaka Wali. (1993). Indigenous Territories and Tropical Forest Management in Latin America. Policy Research Working Paper Series no. 1100, World Bank, Washington.

de Beer, J. de and M. McDermott. 1989. The Economic Value of Non- timber Forest Products in Southeast Asia. Netherlands Committee for IUCN, Amsterdam.

Dewees, P.A. and S.J. Scherr. 1995. Policies and Markets for Non-Timber Tree Products. Draft Working Paper, International Food Policy Research Institute, Washington.

Falconer, J. 1989. Forestry and Nutrition: A Reference Manual. Forestry Department, FAO, Rome.

Falconer, J. 1990. The Major Significance of "Minor" Forest Products: The Local Use and Value of Forests in the West African Humid Forest Zone. Community Forestry Note 6, FAO, Rome.

Falconer, J. 1994. Non-timber Forest Products in Southern Ghana: Main Report. Republic of Ghana Forestry Department and Overseas Development Administration, Natural Resources Institute, Chatham.

Falconer, J. and J.E.M. Arnold. 1989. Household Food Security and Forestry: An Analysis of Socioeconomic Issues. Community Forestry Note 1, FAO, Rome.

FAO. 1987. Small-scale Forest Based Processing Enterprises. Forestry Paper 79, FAO, Rome.

FAO. 1995. Non-Wood Forest Products in Nutrition. Paper prepared for the FAO/GOI Expert Consultation on NonWood Forest Products, Yogyakarta, Indonesia, 17-27 January 1995.

Fernandes, W., Menon, G. and P. Viegas. 1988. Forests, Environment and Tribal Economy: Deforestation, Impoverishment and Marginalisation in Orissa. Indian Social Institute.

Fisseha, Y. 1987. Small- scale Forest Based Processing Enterprises. Forestry Paper 79, FAO, Rome.

Grenand, P. and F. Grenand. 1996. Living in Abundance. The forest of the Wayampi (Amerindians from French Guiana). In: Ruiz Pérez M. and Arnold, J.E.M. (eds). Current Issues in Non-Timber Forest Products Research. pp. 177-196. CIFOR-ODA, Bogor.

Gunatilake, H.M., Senaratine, D.M.A.H. and P. Abeygunawardena. 1993. Role of nontimber forest products in the economy of peripheral communities of Knuckles National Wilderness area of Sri Lanka. Economic Botany 47: $275-281$

Haggblade, S. and C. Liedholm. 1991. Agriculture, Rural Labor Markets, and Evolution of the Rural Nonfarm 
Economy. GEMINI Working Paper No. 19. Growth and Equity through Microenterprise Investments and Institutions (GEMINI) Project, Bethesda, Maryland, USA.

Hecht, S.B., Anderson, A. and P. May. 1988. The subsidy from nature: Shifting cultivation, successional palm forests and rural development. Human Organization 47: 25-35.

Homma, A.K.O. 1996. Modernisation and technological dualism in the extractive economy in Amazonia. In: Ruiz Pérez M. and Arnold, J.E.M. (eds). Current Issues in Non-Timber Forest Products Research. pp. 59-81. CIFOR-ODA, Bogor.

Hopkins, J.C., S.J. Scherr and P.Gruhn. 1994. Food Security and the Commons: Evidence from Niger. Draft report to USAID Niger, IFPRI, Washington.

Jodha, N.S. 1990. Rural Common Property Resources: Contributions and Crisis. Economic and Political Weekly, Quarterly Review of Agriculture 25 (26).

Leach, M. and J. Fairhead. 1994. The Forest Islands of Kissidougou: Social Dynamics of Environmental Change in West Africa's Forest-savanna Mosaic. Report to ESCOR, U.K. Overseas Development Administration.

Liedholm, C. and D.C. Mead. 1987. Small-scale Industries in Developing Countries: Empirical Evidence and Policy Implications. MSU International Development Paper No. 9, Michigan State University: Lansing.

Liedholm, C. and D.C. Mead. 1993. The Structure and Growth of Microenterprises in Southern and Eastern Africa. GEMINI Working Paper No. 36. Growth and Equity through Microenterprise Investments and Institutions (GEMINI) Project, Bethesda,Maryland, USA.

Lynch, O.J. and K. Talbott. 1995. Balancing Acts: Community-Based Forest Management and National Law in Asia and the Pacific. World Resources Institute, Washington.

Madge, C. 1990. Money, Medicine and Masquerades: Women, Collecting and Rural Development in the Gambia. $\mathrm{PhD}$ thesis submitted to the School of Geography, Faculty of Arts of the University of Birmingham, Birmingham.

May, P.H., Anderson, A.B., Balick, M.J. and J. Unruh. 1985. Babaçu palm in the agroforestry systems in Brazil's mid-north region. Agroforestry Systems 3(39):275-295.

Melnyk, M. 1993. The Effects of Sedenterization on Agriculture and Forest Resources in Southern Venezuela. Network Paper 16b, Rural Development Forestry Network, ODI, London.

Nguyen Thi Yen, Nguyen Quang Duc, Vu Manh Thien, Dang Duc Phuong and B.A. Ogle. 1994. Dependency on Forest and Tree Products for Food Security: A Pilot Study in Yen Huong Commune, Ham Yen District, Tuyen Quang Province, North Vietnam. Working Paper 250, Swedish University of Agricultural Sciences, Uppsala.

Ogle, B. 1996. People's dependency on forests for food security. Some lessons learnt from a programme of case studies. In: Ruiz Pérez M. and Arnold, J.E.M. (eds). Current Issues in Non-Timber Forest Products Research. pp. 219-241. CIFOR-ODA, Bogor.

Olsson, G. 1991. Forests and forest product use in Vanuatu and Tonga. Working Paper 2 - RAS/86/036, South Pacific Forestry Development Programme, FAO/UNDP, Port Vila.

Peluso, N.L. 1996. Rattan industries in East Kalimantan, Indonesia. Draft Paper commissioned by FAO. (A condensed version of this paper appears in J.Y. Campbell (ed.), 1991, Case Studies in Forest-based Small-Scale Enterprises in Asia: Rattan, Matchmaking and Handicrafts. pp. 5-28. Community Forestry Case Study 4. FAO, Bangkok.

Peluso, N.L. and C. Padoch. 1996. Changing resource rights in managed forests of West Kalimantan. In Borneo in Transition: People, Forests, Conservation, and Development, pp. 121-136, Padoch and Peluso (eds.), Oxford University Press, Singapore.

Pimental, D., McNair, M., Buck, L., Pimental, M. and J. Kamil. 1997. The Value of Forests to World Food Security. Human Ecology, 25(1):91-120.

Ruiz Pérez and Arnold J.E.M. (eds). 1996. Current Issues in Non-Timber Forest Products Research. CIFOR-ODA, Bogor. 
Shepherd, G. 1992. Managing Africa's Tropical Dry Forests: A Review of Indigenous Methods. Agricultural Occasional Paper 14, Overseas Development Institute, London.

Siebert, S. and Belsky, J.M. 1985. Forest product trade in a lowland filipino village. Economic Botany 39: 522533.

Townson, I.M. 1995a. Forest Products and Household Incomes: A Review and Annotated Bibliography. Tropical Forestry Papers 31. Centre for International Forestry Research and Oxford Forestry Institute, Oxford.

Townson, I.M. 1995b. Patterns of Non-Timber Forest Products Enterprise Activity in the Forest Zone of Southern Ghana. Draft report to the ODA Forestry Research Programme.

WCFSD. 1997. Our Future Our Forests. Final Report of the World Commission on Forests and Sustainable Development. Geneva

Wilkie, D.S. and R.A. Godoy. 1996. Trade, indigenous rain forest economies and biological diversity. Model predictions and directions for research. In: Ruiz Pérez M. and Arnold, J.E.M. (eds). Current Issues in NonTimber Forest Products Research. pp. 83-102. CIFOR-ODA, Bogor. 